\title{
Arbitrarily Primed PCR Analysis of Mycoplasma hyopneumoniae Field Isolates Demonstrates Genetic Heterogeneity
}

\author{
SERGEY ARTIUSHIN† AND F. CHRIS MINION* \\ Veterinary Medical Research Institute, Iowa State University, Ames, Iowa 50011
}

\begin{abstract}
Mycoplasma hyopneumoniae is the primary agent of mycoplasmal pneumonia in swine. In this study we performed an arbitrarily primed PCR (AP-PCR) analysis, in which low-stringency amplification with a single primer was used, to investigate genetic variability in $M$. hyopneumoniae strains and field isolates. We performed preliminary experiments to examine the efficacy of 40 different 10-mer oligonucleotides for priming an AP-PCR with $M$. hyopneumoniae $\mathrm{J}^{\mathrm{T}}$ ( $\mathrm{T}=$ type strain) chromosomal DNA. On the basis of our results, we selected primers OPA-3, OPA-17, and OPB-10 for use in an analysis performed with 23 field isolates. The most informative results were obtained with primer OPA-3. A total of 21 of 23 clinical isolates produced multiband patterns with this primer, while 2 isolates failed to produce any detectable bands. Our data show that $M$. hyopneumoniae is genetically diverse and that $M$. hyopneumoniae strains can be divided into at least six epidemiological subgroups on the basis of AP-PCR results.
\end{abstract}

The mycoplasmas are wall-less prokaryotes that belong to the class Mollicutes and are believed to be the smallest organisms that are capable of self-replication. The genome sizes of mycoplasmas vary from 600 to $1,100 \mathrm{~kb}$, and the chromosomal DNA G + C content of most strains is extremely low (about 26 mol\%). Members of the genus Mycoplasma are isolated from animal hosts, where they may be commensal or pathogenic. Mycoplasma hyopneumoniae is the primary agent of mycoplasmal rhinitis and pneumonia in swine (16). This disease is a worldwide problem that results in large economic losses. There is also increasing evidence that $M$. hyopneumoniae has a predisposing influence on other infections (16). Limited information concerning genetic differences among the strains of $M$. hyopneumoniae is available, and consequently no data relating genetic differences to virulence have been published (7). An understanding of genetic variability in $M$. hyopneumoniae is important for studies of the taxonomy, epidemiology, and pathogenicity of this species.

As a first step in developing a genetic typing scheme, arbitrarily primed PCR (AP-PCR), which is sometimes referred to as random amplified polymorphic DNA analysis, was used to determine the extent of genetic variability in $M$. hyopneumoniae. The use of PCR to "type" clinical isolates is becoming commonplace because of the sensitivity and speed of this method $(10,19,20)$. This technique has also been applied to mycoplasma species by targeting species-specific DNA sequences $(2,4,9,11-13)$. AP-PCR also allows workers to assess genomic variability in different field isolates $(1,8,21)$. Because this method requires less than $50 \mathrm{ng}$ of DNA, it could be particularly important in studies of $M$. hyopneumoniae, a fastidious mycoplasma species which grows slowly and requires expensive specialized media.

M. hyopneumoniae $\mathrm{J}^{\mathrm{T}}\left(=\right.$ ATCC $\left.25934^{\mathrm{T}}\right)(\mathrm{T}=$ type strain) and all of the field isolates of $M$. hyopneumoniae which we used (Table 1) were obtained from R. F. Ross, Veterinary Medical Research Institute, Iowa State University. All of the field iso-

\footnotetext{
* Corresponding author. Mailing address: Veterinary Medical Research Institute, Iowa State University, 1802 Elwood Drive, Ames, IA 50011. Phone: (515) 294-6347. Fax: (515) 294-1401. Electronic mail address: fcminion@iastate.edu.

$\uparrow$ Present address: Department of Veterinary Science, University of Kentucky, Lexington, KY 40546.
}

lates were obtained from clinical samples from diseased swine submitted to the Iowa State University Veterinary Diagnostic Laboratory. These isolates were obtained from different swine herds whose members had mycoplasmal pneumonia symptoms; the herds were located throughout the Midwest (in Iowa, Indiana, and Kentucky). Each isolate was identified by using a fluorescence antibody test (R. F. Ross, Iowa State University), a metabolic inhibition test (6) and a M. hyopneumoniae-specific PCR (2). All mycoplasmas were cultivated in Friis medium supplemented with $20 \%$ acid-adjusted swine serum and $5 \%$ fresh yeast extract for 48 to $72 \mathrm{~h}$ at $37^{\circ} \mathrm{C}$ until the mid-log phase.

To prepare chromosomal DNA, cells from a $10-\mathrm{ml}$ culture were harvested by centrifugation at $20,000 \times g$ for $15 \mathrm{~min}$ at $4^{\circ} \mathrm{C}$, washed with phosphate-buffered saline $(0.14 \mathrm{M} \mathrm{NaCl}, 0.01$ $\mathrm{M}$ sodium phosphate; $\mathrm{pH} 7.3$ ), and resuspended in $100 \mu \mathrm{l}$ of TE buffer (0.01 M Tris, 0.001 M EDTA; pH 8.0). Then $100 \mu \mathrm{l}$ of $1 \%$ sodium dodecyl sulfate and proteinase $\mathrm{K}$ (final concentration, $400 \mu \mathrm{g} / \mathrm{ml}$; Sigma Chemical Co., St. Louis, Mo.) was added, and the mixture was incubated for $1 \mathrm{~h}$ at $37^{\circ} \mathrm{C}$. A $10-\mu \mathrm{l}$ portion of glass milk (Bio 101, Inc., La Jolla, Calif.) was added, and the suspension was incubated for $5 \mathrm{~min}$ at $0^{\circ} \mathrm{C}$. The glass milk-DNA precipitate was washed three times with New Wash buffer (Bio 101, Inc.) without shaking, and the DNA was eluted with $50 \mu \mathrm{l}$ of TE buffer at $46^{\circ} \mathrm{C}$ for $5 \mathrm{~min}$. The DNA concentration of each sample was determined by fluorescence by using a model TKO 100 minifluorometer (Bio-Rad Laboratories, Richmond, Calif.). To verify that the DNA was intact, aliquots were electrophoresed on a Tris-borate- $0.7 \%$ agarose gel, and the gel was stained with ethidium bromide.

Our initial experiments revealed that the presence of contaminating RNA in DNA preparations resulted in nonreproducible AP-PCR data (data not shown). In order to increase reproducibility and ensure high-quality DNA preparations, chromosomal DNA was isolated by using glass milk and was eluted with TE buffer. No RNA was observed in the resulting DNA preparations. Each DNA preparation was then analyzed by performing a $M$. hyopneumoniae-specific PCR (2). All preparations yielded the expected single 456-bp fragment when the PCR primer pair described previously (2) was used (data not shown).

Two primer kits containing a total of 4010 -mer oligonucleotide primers were obtained from Operon Technologies, Inc. Alameda, Calif. To screen for positive reactions, chromosomal 
TABLE 1. Strains and field isolates of $M$. hyopneumoniae used in this study and the reactivities of these strains with primers OPA-3, OPB-10, and OPA-17

\begin{tabular}{|c|c|c|c|c|c|c|c|c|c|c|c|c|c|c|c|c|}
\hline \multirow{3}{*}{ Group } & \multirow{3}{*}{ Strain } & \multirow{3}{*}{$\begin{array}{c}\text { Source of } \\
\text { original } \\
\text { culture }^{a}\end{array}$} & \multirow{3}{*}{$\begin{array}{c}\text { Year } \\
\text { received }^{h}\end{array}$} & \multirow{3}{*}{ Location $^{c}$} & \multicolumn{12}{|c|}{ Reactivity with: } \\
\hline & & & & & \multicolumn{10}{|c|}{ Primer OPA-3 } & \multirow{2}{*}{$\begin{array}{l}\text { Primer } \\
\text { OPB-10 }\end{array}$} & \multirow{2}{*}{$\begin{array}{c}\text { Primer } \\
\text { OPA-17 }\end{array}$} \\
\hline & & & & & $\begin{array}{c}2.5-\mathrm{kb} \\
\text { band }\end{array}$ & $\begin{array}{c}1.8-\mathrm{kb} \\
\text { band }\end{array}$ & $\begin{array}{l}1.6-\mathrm{kb} \\
\text { band }\end{array}$ & $\begin{array}{c}1.4-\mathrm{kb} \\
\text { band }\end{array}$ & $\begin{array}{l}1.3-\mathrm{kb} \\
\text { band }\end{array}$ & $\begin{array}{l}1.0-\mathrm{kb} \\
\text { band }\end{array}$ & $\begin{array}{c}0.8-\mathrm{kb} \\
\text { band }\end{array}$ & $\begin{array}{l}0.7-\mathrm{kb} \\
\text { band }\end{array}$ & $\begin{array}{l}0.6-\mathrm{kb} \\
\text { band }\end{array}$ & $\begin{array}{c}0.5-\mathrm{kb} \\
\text { band }\end{array}$ & & \\
\hline \multirow[t]{5}{*}{ I } & 10954 & VMRI & 1983 & Iowa & - & - & + & - & - & - & + & - & + & - & - & - \\
\hline & P-13129-5 & Armstrong & 1981 & Indiana & - & - & + & - & - & - & + & - & + & - & - & - \\
\hline & P-13129-6 & Armstrong & 1981 & Indiana & - & - & + & - & - & - & + & - & + & - & + & - \\
\hline & P-13129-9 & Armstrong & 1981 & Indiana & - & - & + & - & - & - & + & - & + & - & + & - \\
\hline & P-11318 & Armstrong & 1982 & Indiana & - & + & + & + & - & - & + & - & + & - & + & - \\
\hline \multirow[t]{4}{*}{ II } & $31-9$ & VMRI & 1989 & Kentucky & - & + & + & + & + & - & + & + & + & - & + & - \\
\hline & P-1814-5 & Armstrong & 1981 & Indiana & - & + & + & + & + & - & + & + & + & - & + & + \\
\hline & P-1814-10 & Armstrong & 1981 & Indiana & - & + & + & + & + & - & + & - & + & - & + & - \\
\hline & P-5782 & Armstrong & 1980 & Indiana & - & + & + & + & + & - & + & - & + & - & + & - \\
\hline \multirow[t]{4}{*}{ III } & 11928 & VMRI & 1983 & Iowa & - & + & + & + & + & - & + & - & + & - & - & + \\
\hline & P-6053-4 & Armstrong & 1981 & Indiana & - & - & + & + & + & + & + & - & + & - & - & + \\
\hline & P-6053-3 & Armstrong & 1981 & Indiana & - & + & + & + & + & - & + & - & + & - & - & - \\
\hline & P-6053-2 & Armstrong & 1981 & Indiana & - & + & + & + & + & - & + & - & + & - & - & - \\
\hline \multirow[t]{7}{*}{ IV } & $18-14$ & VMRI & 1989 & Kentucky & - & + & - & + & + & - & - & + & - & - & + & - \\
\hline & $3-14$ & VMRI & 1989 & Kentucky & - & + & - & + & + & - & - & + & - & - & + & - \\
\hline & $16-14$ & VMRI & 1989 & Kentucky & - & + & - & + & + & - & - & + & - & - & - & - \\
\hline & $4-14$ & VMRI & 1989 & Kentucky & + & + & - & + & + & - & - & + & - & - & - & - \\
\hline & P-5298-1 & Armstrong & 1982 & Indiana & - & + & + & + & + & - & - & + & - & - & - & - \\
\hline & $\begin{array}{c}\mathrm{J}^{\mathrm{T}}(=\mathrm{ATCC} \\
\left.25934^{\mathrm{T}}\right)\end{array}$ & & & & - & + & - & + & + & + & - & - & - & - & + & + \\
\hline & 10986 & VMRI & 1983 & Iowa & - & + & - & + & + & - & - & - & - & - & - & - \\
\hline \multirow[t]{2}{*}{ V } & 9275 & VMRI & 1983 & Iowa & - & + & - & + & + & - & + & - & - & + & - & - \\
\hline & 10731 & VMRI & 1983 & Iowa & - & + & - & + & - & - & + & - & - & - & - & - \\
\hline \multirow[t]{2}{*}{ VI } & $11684 \mathrm{C}$ & VMRI & 1983 & Iowa & - & - & - & - & - & - & - & - & - & - & + & - \\
\hline & $37-9$ & VMRI & 1989 & Kentucky & - & - & - & - & - & - & - & - & - & - & - & - \\
\hline
\end{tabular}

"VMRI, Veterinary Medical Research Institute, Iowa State University, Ames; Armstrong, C. Armstrong, Purdue University Veterinary Diagnostic Laboratory, West Lafayette, Ind.

${ }^{b}$ The year the isolate was received at the Veterinary Medical Research Institute; the actual year of isolation is unknown in most cases.

c Geographical location where the strain was isolated.

DNA from strain $\mathrm{J}^{\mathrm{T}}$ was amplified in a $30-\mu$ l reaction mixture which contained $30 \mathrm{ng}$ of mycoplasma genomic DNA, $2 \mathrm{mM}$ $\mathrm{MgCl}_{2}, 5$ pmol of primer, $100 \mu \mathrm{M}$ dATP (Pharmacia Fine Chemicals), $100 \mu \mathrm{M}$ dCTP (Pharmacia), $100 \mu \mathrm{M}$ dGTP (Pharmacia), $100 \mu \mathrm{M}$ dTTP (Pharmacia), $1 \times$ AmpliTaq buffer, and $1 \mathrm{U}$ of AmpliTaq DNA polymerase (Perkin-Elmer Cetus). The reaction conditions were then optimized for reproducibility with primer OPA-3 ( $3 \mathrm{mM} \mathrm{MgCl}_{2}, 20 \mathrm{pmol}$ of primer, and each nucleotide at a concentration of $200 \mu \mathrm{M}$ ). The program used for all PCR was a 45-cycle program, with each cycle consisting of $1 \mathrm{~min}$ at $92^{\circ} \mathrm{C}, 1 \mathrm{~min}$ at $36^{\circ} \mathrm{C}$, and $2 \mathrm{~min}$ at $72^{\circ} \mathrm{C}$. An Ericomp Twin Block thermal cycler was used for amplification. A 15- $\mu$ l portion of amplification reaction products was analyzed by electrophoresis in Tris-borate- $0.7 \%$ agarose- $0.4 \%$ Synergel (Diversified Biotech, Boston, Mass.) gels, the bands were detected by staining with ethidium bromide, and the image was digitized by using a model 4900 high-performance charge-coupled device (CCD) camera (Cohu, Inc., San Diego, Calif.).

Only 6 of the 40 primers used (primers OPA-3 [AGTCAGC CAC], OPA-17 [GACCGCTTGT], OPB-8 [GTCCACACGG], OPB-10 [CTGCTGGGAC], OPB-14 [TCCGCTCTGG], and OPB-18 [CCACAGCAGT]) gave positive results under the PCR conditions used. Primers OPB- 8 and OPB- 18 produced a single band with strain $\mathrm{J}^{\mathrm{T}}$ DNA. Primers OPA-17 and OPB-14 produced strong bands, and primers OPB-10 and OPA-3 pro- duced multiple bands. Primers OPA-3, OPA-17, and OPB-10 were used in subsequent studies with field isolates of $M$. hyopneumoniae.

The results of one set of AP-PCR with primer OPA-3 are shown in Fig. 1. A total of 21 of 23 M. pneumoniae field isolates produced a multiple-band pattern, while 2 isolates, strains $11684 \mathrm{C}$ and $37-9$, failed to produce any signal. The latter result can be interpreted as the loss of specific sites for primer binding in the chromosomal DNAs of these isolates since these DNAs gave the appropriate bands when they were examined by using the species-specific PCR described previously (2) (data not shown).

The sizes of the primer OPA-3-generated fragments were determined from digitized images by using the GelReader 2.0.5 software (National Center for Supercomputing Applications, University of Illinois at Urbana-Champaign). On the basis of these results, each strain was visually coded for the presence or absence of 10 different bands plus reactivity to primers OPA-17 and OPB-10 (Table 1). Although there were variations in the intensities of the bands obtained with primer OPA-3, these variations were not included in the analysis. The data for 24 strains (strain $\mathrm{J}^{\mathrm{T}}$ and 23 independent field isolates) were then analyzed with the Phylogenetic Analysis Using Parsimony package (PAUP version 3.1.1) (17). We also included in this analysis the AP-PCR results obtained by using primers 


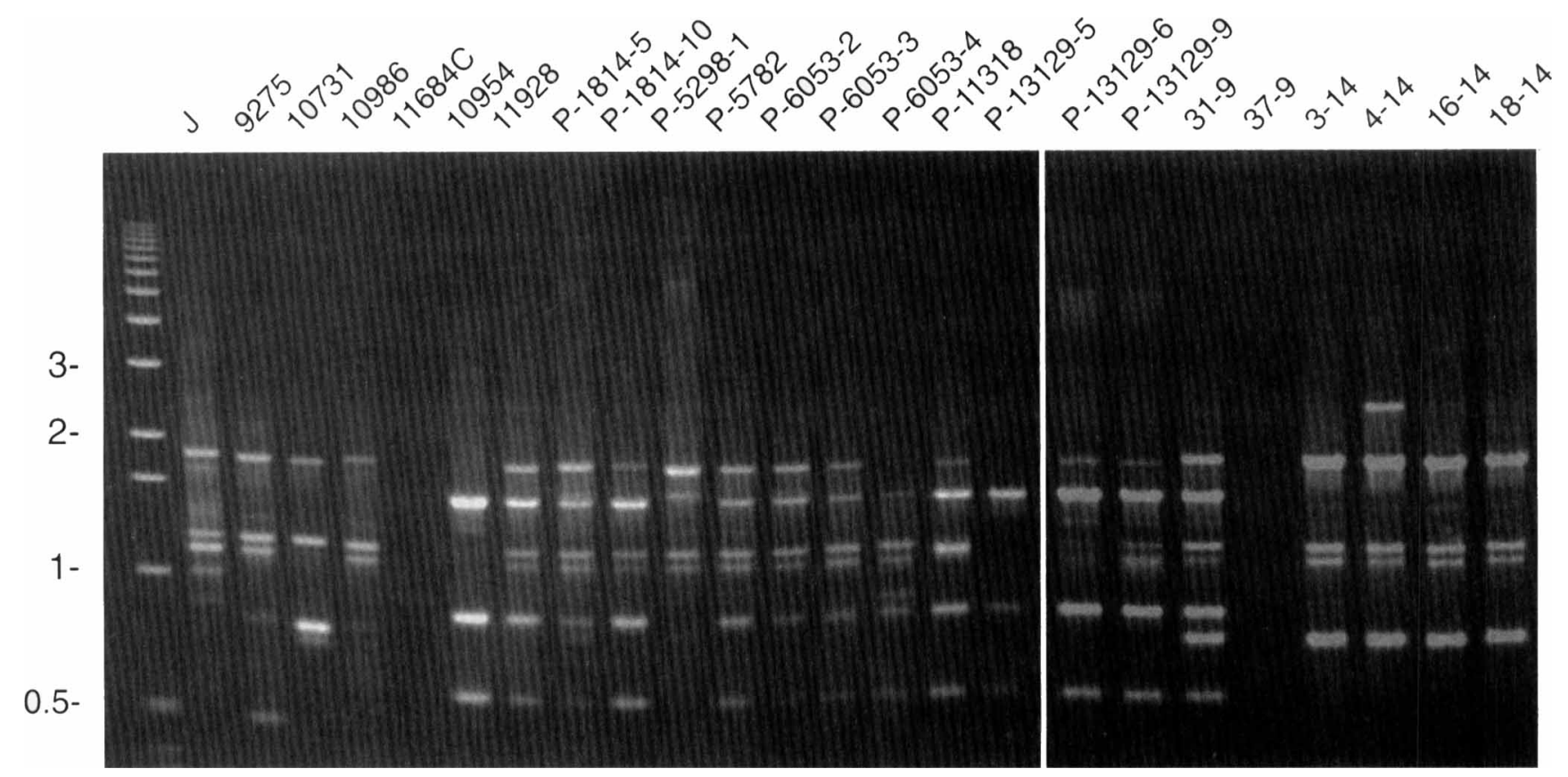

FIG. 1. One set of AP-PCR for different $M$. hyopneumoniae field isolates obtained by using primer OPA-3. AP-PCR were performed in mixtures containing 3 mM $\mathrm{MgCl}_{2}$ and $20 \mathrm{pmol}$ of primer and were analyzed as described in the text. The lanes contain AP-PCR products obtained with the DNAs of selected strains. The lane on the left contained a kilobase ladder molecular weight standard (Bethesda Research Laboratories), and the numbers on the left indicate fragment sizes (in kilobases). The figure is a composite of two gels that were electrophoresed simultaneously; all of the samples used were prepared on the same day under identical conditions. The gels were digitized as described in the text by using a Macintosh IIci computer equipped with a video board (Scion Corp., Frederick, Md.). The resulting TIFF files were cropped and assembled in Adobe Photoshop and were labeled in Aldus FreeHand.

OPA-17 and OPB-10 (Table 1). Heuristic analyses were performed with stepwise random addition by using branch swapping with tree bisection and reconnection. A consensus tree was then generated from the equally most parsimonious trees by using the $50 \%$ majority rule (Fig. 2 ).

The $M$. hyopneumoniae isolates belonged to six separate groups (Fig. 2). Group I included two strains that failed to react with primer OPA-3. One of these strains, strain 37-9, failed to react with any of the PCR primers used, although it did react with the $M$. hyopneumoniae-specific primer pair (data not shown). Our results also revealed similarities of band patterns within geographical regions. For instance, four of the five isolates in group II were isolated from diseased swine from Indiana. As far as we could determine, each of these isolates was from a different swine farm within the state. The members of each of the four larger groups, groups II through V, exhibited similar geographical distributions (Table 1). Even within a single geographical location, however, there were differences in the band patterns and the reactivities as determined by AP-PCR with the three oligomers (Table 1). The results of our analyses of the data by state are shown in Fig. 3. In each of these analyses 100 replicates were examined. Even grouping by state clearly revealed variability in the band patterns. In contrast, Mycoplasma pneumoniae appears to be highly clonal in nature when it is examined by AP-PCR (18).

Most of the information about $M$. hyopneumoniae which we have has been obtained by analyzing type strain J (= ATCC 25934), which is thought to be indistinguishable from field strains on the basis of growth characteristics, metabolic inhibition with type-specific antisera, and immunological tests (14, 15). Chromosomal heterogeneity was also observed in $M$. hyopneumoniae field strains when a pulsed-field gel electrophoresis analysis of restriction enzyme digests was performed (7).

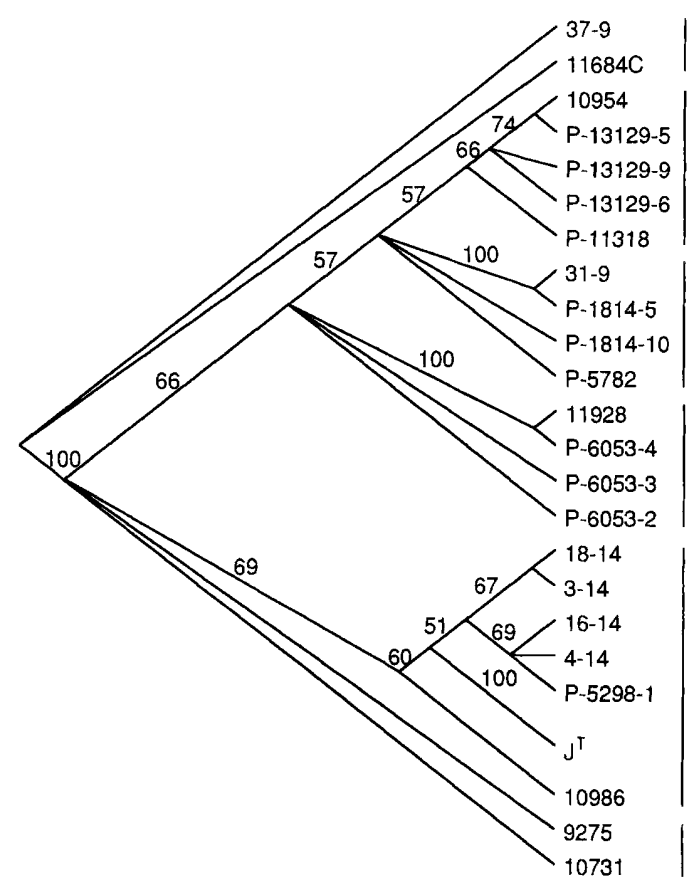

Group IV

Group 1

Group $\|$

Group III

FIG. 2. Majority rule consensus grouping of $24 M$. hyopneumoniae strains. The AP-PCR band patterns of $24 M$. hyopneumoniae strains were analyzed by performing a heuristic analysis with random stepwise addition of 100 replicates as described in the text. A total of 70 equally parsimonious trees were generated, and a consensus tree was generated by using the $50 \%$ majority rule. The numbers are the percentages of trees containing particular branch points. 

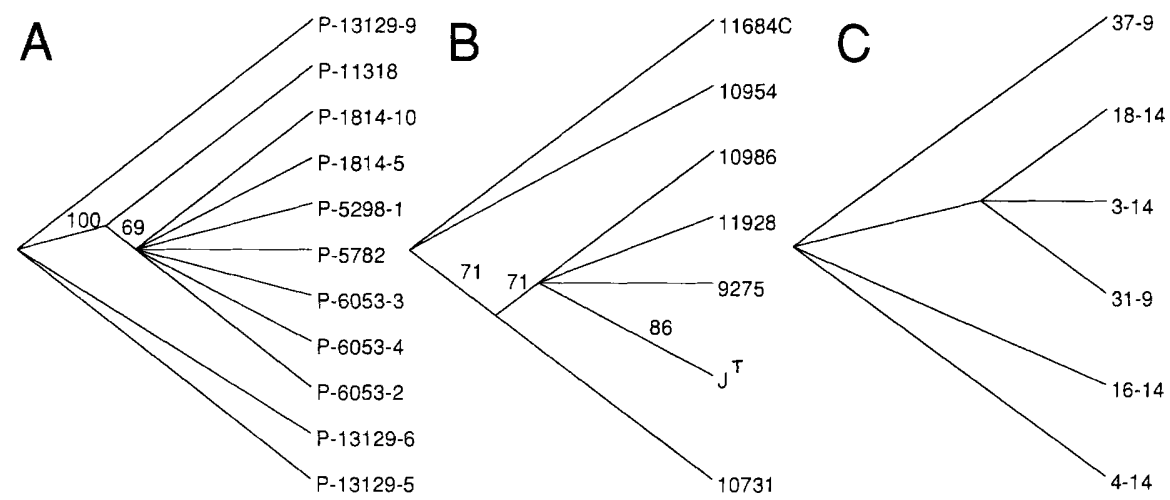

FIG. 3. Analysis of AP-PCR data by state. The data were sorted by state, and each resulting group was analyzed individually as described in the text. We used random stepwise addition in this analysis. Majority rule consensus trees were constructed for the strains from Indiana (A) and Iowa (B). Only one parsimonious tree was generated with the strains from Kentucky $(\mathrm{C})$. The numbers are the percentages of trees containing particular branch points.

Antigen preparations from broth-grown $M$. hyopneumoniae cultures contain large amounts of contaminating broth proteins, a common problem in studies with mycoplasmas $(5,22)$ which complicates protein and immunological analyses. Consequently, the differences in virulence between avirulent strain $\mathrm{J}^{\mathrm{T}}$ and field isolates are not easily explained.

Our data demonstrated that there is significant genetic heterogeneity in $M$. hyopneumoniae field isolates. The true extent of the heterogeneity in $M$. hyopneumoniae is not known since single base pair changes in the DNA sequence could result in the loss or acquisition of single bands. Analyses of additional field isolates from other geographical regions may reveal additional groups, but this technique is only one measure of genetic relatedness and its resolving power is limited. Our results must still be interpreted cautiously since two dissimilar PCR products may resolve together and variability in a region may not be revealed by agarose gel electrophoresis.

Since not all of the strains which we studied have been examined for disease potential by using a swine challenge model, it is not possible to correlate genetic heterogeneity with virulence with certainty. However, it can be safely assumed that each of the field isolates is pathogenic since the strains were isolated from diseased swine that exhibited mycoplasmal pneumonia symptoms.

It is thought that mycoplasmas evolve rapidly, and our APPCR results may simply be another reflection of this evolutionary process. We do not know whether the variation identified in this study was due to genomic instability or whether substantial evolution has occurred in some $M$. hyopneumoniae populations because of selective pressures. This could be ascertained by studying a single well-defined isolate as it progresses through a swine herd to determine how rapidly genomic variation occurs in this species. Chromosomal rearrangements have been identified previously in the mycoplasmas (3), which may account for some of the variability observed in the field isolates. AP-PCR may be useful for studying genomic variation in the field and thereby may increase our knowledge concerning mycoplasmal pathogenesis. This technique can also be performed easily and could form the basis of a useful typing scheme for $M$. hyopneumoniae.

We thank Barbara Zimmerman-Erickson and R. F. Ross for supplying the original cultures used in this study. We also thank Mel Duvall for his assistance in interpreting the parsimony analysis.

This work was supported by Cooperative State Research Service grant 91-37204-6488 from the United States Department of Agriculture. F.C.M. is the recipient of U.S. Public Health Service Research
Career Development Award 1K04 AI-01021 from the National Institute of Allergy and Infectious Diseases.

\section{REFERENCES}

1. Akopyanz, N., N. O. Bukanov, T. U. Westblom, S. Kresovich, and D. E. Berg 1992. DNA diversity among clinical isolates of Helicobacter pylori detected by PCR-based RAPD fingerprinting. Nucleic Acids Res. 20:5137-5142.

2. Artiushin, S., L. Stipkovits, and F. C. Minion. 1993. Development of polymerase chain reaction primers to detect Mycoplasma hyopneumoniae. Mol Cell. Probes 7:381-385

3. Bhugra, B., and K. Dybvig. 1992. High-frequency rearrangements in the chromosome of Mycoplasma pulmonis correlate with phenotypic switching. Mol. Microbiol. 6:1149-1154.

4. Blanchard, A., W. Hamrick, L. Duffy, K. Baldus, and G. H. Cassell. 1993. Use of the polymerase chain reaction for detection of Mycoplasma fermentans and Mycoplasma genitalium in the urogenital tract and amniotic fluid. Clin. Infect. Dis. 17:S272-S279.

5. Bradbury, J. M., and F. T. W. Jordan. 1972. Studies on the adsorption of certain medium proteins to Mycoplasma gallisepticum and their influence on agglutination and haemagglutination reactions. J. Hyg. Camb. 70:267-279.

6. Clyde, W. A. J. 1983. Growth inhibition tests, p. 405-409. In S. Razin and J. G. Tully (ed.), Methods in mycoplasmology. Academic Press, New York

7. Frey, J., A. Haldimann, and J. Nicolet. 1992. Chromosomal heterogeneity of various Mycoplasma hyopneumoniae field strains. Int. J. Syst. Bacteriol. 42: 275-280.

8. Geary, S. J., M. H. Forsyth, S. A. Saoud, G. Wang, D. E. Berg, and C. M. Berg. 1994. Mycoplasma gallisepticum strain differentiation by arbitrary primer PCR (RAPD) fingerprinting. Mol. Cell. Probes 8:311-316.

9. Grau, O., R. Kovacic, R. Griffais, and L. Montagnier. 1993. Development of a selective and sensitive polymerase chain reaction assay for the detection of Mycoplasma pinum. FEMS Microbiol. Lett. 106:327-334.

10. Haas, W. H., W. R. Butler, C. L. Woodley, and J. T. Crawford. 1993. Mixedlinker polymerase chain reaction-a new method for rapid fingerprinting of isolates of the Mycobacterium tuberculosis complex. J. Clin. Microbiol. 31: 1293-1298.

11. Harasawa, R., K. Koshimizu, O. Takeda, T. Uemori, K. Asada, and I. Kato. 1991. Detection of Mycoplasma hyopneumoniae DNA by the polymerase chain reaction. Mol. Cell. Probes 5:103-109.

12. Hopert, A., C. C. Uphoff, M. Wirth, H. Hauser, and H. G. Drexler. 1993 Specificity and sensitivity of polymerase chain reaction (PCR) in comparison with other methods for the detection of mycoplasma contamination in cell lines. J. Immunol. Methods 164:91-100.

13. Nascimento, E. R., R. Yamamoto, K. R. Herrick, and R. C. Tait. 1991. Polymerase chain reaction for detection of Mycoplasma gallisepticum. Avian Dis. 35:62-69.

14. Ro, L. H., and R. F. Ross. 1983. Comparison of Mycoplasma hyopneumoniae strains by serological methods. Am. J. Vet. Res. 44:2087-2094.

15. Rose, D. L., J. G. Tully, and R. G. Wittler. 1979. Taxonomy of some swine mycoplasmas: Mycoplasma suipneumoniae Goodwin et al. 1965, a later, objective synonym of Mycoplasma hyopneumoniae Mare and Switzer 1965, and the status of Mycoplasma flocculare Meyling and Friis 1972. Int. J. Syst. Bacteriol. 29:83-91.

16. Ross, R. F. 1986. Mycoplasmal disease, p. 469-483. In A. D. Leman, B. Straw, R. D. Glock, W. L. Mengeling, R. H. C. Penny, and E. Scholl (ed.), Diseases of swine, 6th ed. Iowa State University Press, Ames.

17. Swofford, D. 1993. PAUP: phylogenetic analysis using parsimony, version 3.1 . Illinois Natural History Survey, Champaign. 
18. Ursi, D., M. Ieven, H. van Bever, W. Quint, H, G. M. Niesters, and H. Goossens. 1994. Typing of Mycoplasma pneumoniae by PCR-mediated DNA fingerprinting. J. Clin. Microbiol. 32:2873-2875.

19. van Belkum, A., M. Struelens, and W. Quint. 1993. Typing of Legionella pneumophila strains by polymerase chain reaction-mediated DNA fingerprinting. J. Clin. Microbiol. 31:2198-2200.

20. Versalovic, J., C. R. Woods, P. R. Georghiou, R. J. Hamill, and J. R. Lupski. 1993. DNA-based identification and epidemiologic typing of bacterial patho- gens. Arch. Pathol. Lab. Med. 117:1088-1098.

21. Welsh, J., C. Pretzman, D. Postic, I. Saint Girons, G. Baranton, and M. McClelland. 1992. Genomic fingerprinting by arbitrary primed polymerase chain reaction resolves Borrelia burgdorferi into three distinct phylogenetic groups. Int. J. Syst. Bacteriol. 42:370-377.

22. Yaguzhinskaya, O. E. 1976. Detection of serum proteins in the electrophoretic patterns of total proteins of mycoplasma cells. J. Hyg. Camb. 77: 189-199. 